\author{
В. Е. КАЗМИРЧУК (Киев)
}

\title{
ДЛИННЫЙ ПУТЬ К ИСЦЕЛЕНИЮ (редкие неклассические заболевания человека)
}

\author{
ООО «Институт иммунологии, аллергологии и реабилитации»
} <institut_immunologii@ukr.net>

\begin{abstract}
Приведены случаи неклассических редких заболеваний человека, требующих особого внимания к разным паразитарным заболеваниям. Часто под «маской» неизвестной идиопатической патологии с аллергическими аутоиммунными проявлениями могут скрываться различные паразитарные болезни, требующие от врача тщательного сбора анамнеза и диагностики. Лечение пациентов следует начинать с установления этиологического фактора на любом уровне и пока не выявлен патоген лечение не может быть эффективным.
\end{abstract}

Ключевые слова: паразиты, иммунитет, шистосомоз, анизокидоз, акариазы, грибы аспергиллёзы, онхоцеркозы.

Введение. Медицинская практика менее совершенна, чем медицинская наука. Временной промежуток между открытием и внедрением иногда длится много десятилетий. В середине прошлого столетия синтезированы первые антибиотики и появилась надежда на устранение бактериальной инфекции. Однако бактерии очень быстро вырабатывают устойчивость и становятся не чувствительными к первому поколению антибиотиков. Синтезируются антибиотики второго, третьего и четвертого поколений. В настоящее время имеют место последствия масштабной антибиотикотерапии в виде грибковой суперинфекции, снижения иммунитета и др. Чаще возникают случаи заболеваний, при которых антибиотики всех четырёх поколений не оказывают влияния на бактериальную инфекцию.

В течение последних 50-60 лет появились бактерии, устойчивые ко всем поколениям антибиотиков. Вскоре были открыты бактерии со свойствами суперантигенов, влияние которых на иммунную систему нарушает нормальный иммунный ответ. Значительное количество многих бактерий, ранее считавшихся условнопатогенными, становятся причиной генерализованного заболевания: стафилококковой, стрептококковой инфекции, грибов, плесени, Helicobacter pylori.

В 50-х годах прошлого столетия в ветеринарии была научно обоснована роль хеликобактерной инфекции как суперантигена в развитии язвенной болезни у свиней и получена эффективность лечения заболевания с учётом выявленной инфекции. Вместе с тем большинство практических врачей, «несмотря на протоколы лечения», и в настоящее время считают Helicobacter pylori условнопатогенной бактерией.

Выражение древних медиков «лечить не болезнь, а больного» в настоящее время стало особенно актуальным в связи с введением лечения по протоколам. «Протокольное лечение - изобретение фарм-бизнеса», т. е. без тщательного обследования больного и выявления первопричины заболевания. Такая терапия месяцами не даёт эффекта и заставляет больных обращаться от одного специалиста к другому с жалобами на отдельные симптомы или синдромы патологии: длительную субфебрильную температуру тела, сниженную трудоспособность, хроническую усталость и др. Повсеместное ухудшение экологии, широкое использование антибактериальных, антигистаминных, сульфаниламидных, гормональных препаратов, цитостатиков привело к появлению стёртых, неклассиче- 
ских проявлений патологии, не соответствующей нозологическим единицам Международной классификации болезней (МКБ-10).

В последние годы все чаще наблюдают пациентов с длительным течением системной грибковой инфекции или плесени. Как известно, к грибковым инфекциям чаще всего приводит не только длительная или бесконтрольная антибиотикотерапия, а также использование антибиотиков в сельском хозяйстве и промышленности.

У каждого второго пациента, обратившегося к нам за консультацией, был установлен диагноз аллергии. К сожалению, этот диагноз устанавливают при любых проявлениях повторяющейся сыпи, зуда, а также непереносимости продуктов питания и др. Медицинская наука полстолетия тому назад разграничила термины аллергия и псевдоаллергия. Однако антигистаминные препараты во всём мире используют без каких-либо оснований и ограничений при любой вышеуказанной симптоматике. В США, по протоколам лечения больных аллергией, приём антигистаминных препаратов назначают длительное время. Десять лет назад в научной литературе появилась статья о 52 случаях летальных исходов при длительном использовании антигистаминных препаратов в связи с их токсическим влиянием на сердечно-сосудистую систему. Ещё в 1980 г. нами был доказан факт иммуносупрессии димедролом. Таким образом, учитывая доказанный факт имуносупрессии, приём антигистаминных препаратов должен быть запрещён для длительного применения.

В настоящее время мы реже встречаемся с такими системными заболеваниями, как ревматизм, ревматоидный артрит. Тем не менее, пациенты с активными формами стафилококковой или стрептококковой инфекции системного характера встречаются достаточно часто. Таким образом, при жалобах системного характера - субфебрилитет, слабость, лёгкая утомляемость - необходимо в первую очередь исключить известные суперантигены, поскольку, чем их активность выше, тем тяжелее протекает любая патология.

Валеодиагностика - скринингдиагностика соматических заболеваний человека и определение изменений электрофизиологических реакций организма. Для этого используют следующие параметры: математико-статический (жалобы, анамнез жизни и болезни, оперативные вмешательства, частота пульса, дыхания, электрофизические воздействия физиологических раздражителей, таких как звук, свет и электромагнитный раздражитель). Электрофизиологический раздражитель создаёт ответную реакцию вегетативных функций пациента во время исследования конкретных органов и отклонение получаемых спектрографических параметров и маркирование очаговых процессов, что даёт врачу возможность осуществить системный анализ спектрографических показателей проводимости тканей, определение причинно-следственных связей развития патологических изменений в органах и системах. Врач использует эталонную базу спектрограмм, достоверно выявленную у пациентов с подтверждённым диагнозом (традиционные лабораторные и инструментальные методы). Далее проводят сравнение этой базы с данными пациента. Возможно и выявление токсического влияния микробиологического биоценоза (паразиты, вирусы, бактерии, грибы) на комплексный и селективный гомеостаз. Третья составляющая диагностики - электрический сигнал в диапазоне 1,8 В, определённой частоты, соответствующей конкретному органу, в котором реализуется импедансометрия (Европейский сертификат медицинского прибора от Института сертификации и тестирования в Дармштадте 25.01.2008 г.).

Гельминтозы Шистосомоз (шистосоматоз, бильгарциоз) - тропическое паразитарное заболевание, вызываемое кровяными сосальщиками (трематоды) из рода Schistosoma (рис. 1). Характеризуется дерматитом (в период внедрения паразитов в кожу) с последующим развитием лихорадки, интоксикации, уртикарной сыпи, спленомегалии, эозинофилии, поражения кишечника или мочеполовых органов. Клиническая картина при шистосомозе обусловлена главным образом развитием иммуноаллергической реакции на яйца паразитов [4]. 


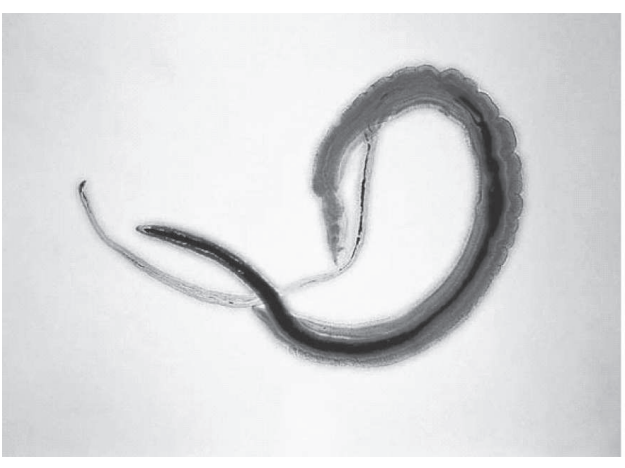

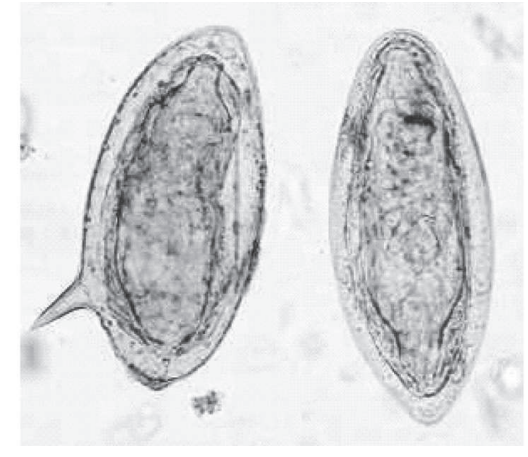

6

Рис. 1. Шистосома [4]:

$a$ - взрослая особь; 6 - яйца после окрашивания

Промежуточные хозяева этих трематод - пресноводные брюхоногие моллюски, окончательный хозяин - человек, млекопитающие животные и птицы. Шистосоматиды, для которых окончательными хозяевами являются животные или птицы, в коже человека гибнут, вызывая лишь первичный дерматит. Шистосоматиды рода Schistosoma, паразитирующие в организме людей, в результате активного движения и лизиса тканей проникают в сосудистое русло и мигрируют в венозные сплетения пищеварительного канала или мочевого пузыря, в которых самки начинают откладывать яйца.

Во всём мире инфицировано более 207 млн человек, а риску инфицирования подвергается около 700 млн в 74 эндемических странах, имеющих контакт с заражённой паразитами водой, во время сельскохозяйственной деятельности, домашней работы или купания. По оценке ВОЗ, от шистосомоза ежегодно умирают от 20 до 200 тыс. человек.

Развитие болезни следующее: через 10-15 мин в месте внедрения в кожу церкариев возникает интенсивный зуд, иногда крапивница, а в течение суток появляется транзиторная пятнистая сыпь. Через 1-2 мес после заражения шистосомами развивается острый шистосомоз, или лихорадка Катаямы. Болезнь характеризуется внезапным началом: лихорадкой в течение 2 нед и более, сухим кашлем, появлением уртикарной сыпи, гепатоспленомегалией, лейкоцитозом, эозинофилией, ускорением СОЭ.

Кишечный шистосомоз может вызывать боль в области живота, диарею и появление крови в кале. В запущенных случаях наблюдается гепатомегалия (увеличение печени), что часто связано с накоплением жидкости в брюшной полости и гипертензией абдоминальных кровяных сосудов. В таких случаях может также наблюдаться увеличение селезёнки [5].

Классическим признаком мочеполового шистосомоза является гематурия (кровь в моче). В запущенных случаях часто развивается фиброз мочевого пузыря и мочеточников, поражаются почки. Возможным осложнением на последних стадиях является рак мочевого пузыря. У женщин мочеполовой шистосомоз может приводить к поражениям половых органов, вагинальному кровотечению, боли во время полового акта и образованию узлов на наружных половых органах. У мужчин мочеполовой шистосомоз может вызывать развитие патологии семенных пузырьков, поджелудочной железы и других органов. Эта болезнь может иметь и другие длительные необратимые последствия, включая бесплодие.

Для выявления яиц кишечного шистосомоза в образцах фекалий можно применять методику с использованием окрашенного метиленовой синью целлофана, пропитанного глицерином, или предметных стёкол.

Прогноз благоприятный при своевременной специфической терапии [6].

Муж с женой обратились за консультацией по поводу жжения и дискомфорта в зоне половых органов. До этого обследованы во многих клиниках Украины, Институте уроло- 
гии и нефрологии и некоторых европейских клиниках. Однако патологии мочеполовой системы не выявлено. Пара была направлена на валеодиагностику, с помощью которой диагностирован шистосомоз половых органов. Впоследствии диагноз был подтверждён лабораторным исследованием антител к шистосоме. После назначенного лечения клиническая симптоматика исчезла.

Анизакидоз - новая, важного значения проблема, с которой недостаточно знакомы врачи клинической медицины. С 1993 г. эта инвазия привлекла к себе внимание в связи с поставкой в Украину больших партий солёной норвежской и голландской сельди, в органах и тканях которой были обнаружены личинки, идентифицированные как личинки нематод семейства Anisakidae (рис. 2).

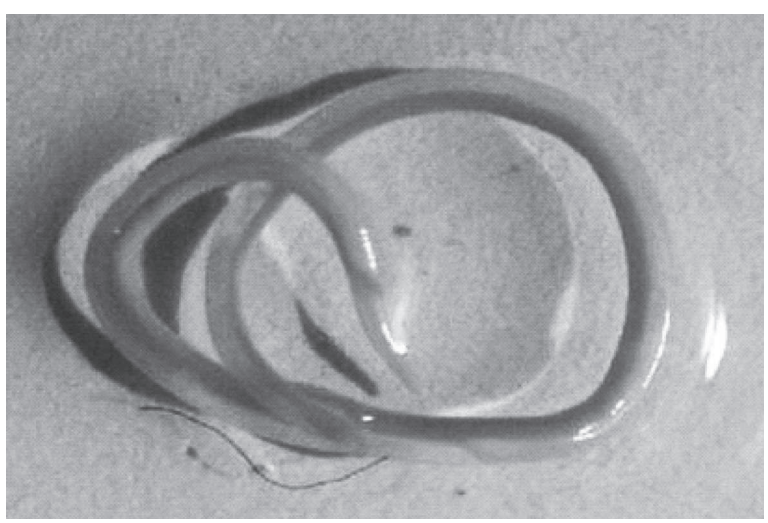

Рис. 2. Половозрелые особи анизакиды [17]

Впервые у человека анизакидоз (болезнь сельдяных червей, болезнь тресковых червей) зарегистрирован в Голландии в 1955 г. после употребления в пищу сельди слабого посола. Позже сообщения о заражении людей этими гельминтами стали появляться чаще и в настоящее временя зарегистрированы тысячи случаев анизакидоза в странах Европы, Северной и Южной Америки, Юго-Восточной Азии [2].

С каждым годом в мире в пищевом рационе человека увеличивается объём морепродуктов. В результате этого морская рыба, креветки, кальмары, завозимые из разных стран полуфабрикаты, всё чаще появляются в рыбных отделах магазинов и рынков.

Во многих городах Украины и России открываются рестораны, в которых любители экзотических блюд японской и китайской кухни употребляют сырую и полусырую рыбу с острыми приправами. К сожалению, не всегда есть гарантия, что эта рыба не содержит живых личинок анизакид и не приведёт к заражению человека. О. Н. Давыдов и соавт. [1] провели исследование морской рыбы, которая поступает на рынки Украины в свежем, замороженном и солёном виде. В результате исследования 1997 разных видов рыб установлена следующая инвазированность анизакидами: 41 \% атлантической сельди, 25 \% трески, 41 \% путассу, 20,5 \% салаки, 34 \% минтая, 35,6 \% мерлузы, 28,1 \% скумбрии, 21,4 \% терпуга, 46,4 \% нототении, 15,6 \% шпрот, 28 \% сайды, 31,4 \% барабульки, 27,2 \% лиманды. Тихоокеанская скумбрия у побережья Японии заражена на 100 \%, серебристый хек - на $53 \%$.

Заражению способствуют пищевые привычки, обычаи кулинарной обработки рыбы, икра слабого посола, национальные блюда, не требующие тщательной термической обработки, - «хе», «тела», «сашими» и др. [3].

Патогенез и клиника следующие: живые личинки анизакид, проглоченные с рыбой или рыбопродуктами, попав в пищеварительный канал, активно внедряются головным концом в подслизистую оболочку любого отдела - от желудка до толстой кишки, но чаще желудка и тонкой кишки. Возникающее воспаление сопровождается эозинофильной инфильтрацией, отёком, геморрагиями, изъязвлением вплоть до развития эозинофильного флегмонозного энтерита [18].

Заболевание сопровождается нарушением секреторной и двигательной функций кишечника. Соответственно нарушается процесс переваривания и усвоения пищи [10].

Анизакидоз протекает как острое заболевание с аллергическими симптомами. Инкубационный период при желудочной локализации процесса - от 1 до 12 ч, при кишечной локализации - 1-2 нед. 
Больные жалуются на схваткообразную боль в животе, тошноту, рвоту, иногда кровавую, симптомы, напоминающие острый гастрит, энтерит, непроходимость кишечника, аппендицит. Известны случаи с явлениями «острого живота», заканчивающиеся оперативным вмешательством и даже летальным исходом [17].

При проникновении личинок в слизистую оболочку желудка может образоваться язва, полип или опухоль.

Девочка 15 лет обратилась с подозрением на системное заболевание соединительной ткани с жалобами на длительный (в течение года) субфебрилитет, головную боль, усталость, боль в суставах. Находилась в детском отделении аутоиммунной патологии Киева, получала протокольное лечение, диагноз верифицировать не удалось. Лечащий квалифицированный специалист направил на обследование в Институт иммунологии в связи с отсутствием эффекта от проводимого лечения. Обращали на себя внимание высокие показатели интоксикации организма (токсикогенная зернистость нейтрофильных гранулоцитов крови) при отсутствии показателей системного воспаления и антител к аскаридам, лямблиям и токсокарам. В связи с вышеуказанным в начале была проведена антипаразитарная терапия пирантелом однократно, фуразолидоном 5 дней, альбендазолом 3 дня. В течение 3 мес повышения температуры тела не наблюдалось, симптомы заболевания исчезли. Через 3 мес начался рецидив указанной патологии. Больная направлена на валеодиагностику. В результате обследования выявлены четыре вида паразитов, находящихся в печени и поджелудочной железе, а в желудке - анизакиды. После проведённого комплексного лечения температура тела нормализовалась, симптоматика исчезла.

Онхоцеркоз (речная слепота) - гельминтоз из группы филяриатозов, характеризуется образованием подкожных узлов, поражением кожи и глаз (рис. 3).

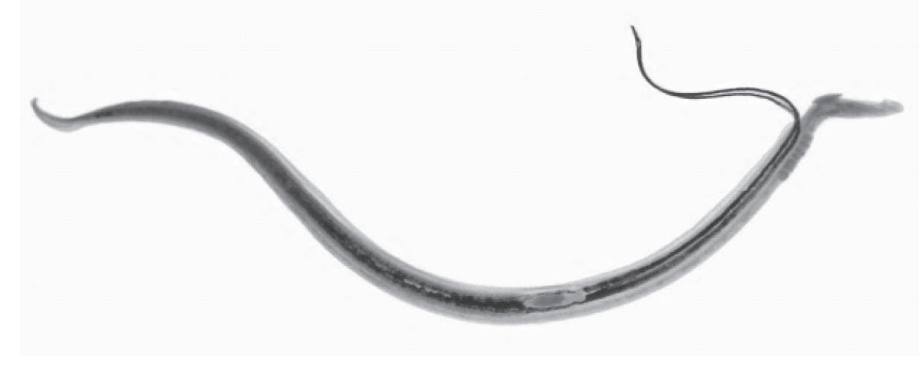

Pис. 3. Onchocerca volvulus [16]

Клиническая картина паразитоза обусловлена иммуноаллергическими реакциями на гибнущий микрофилярий. При тяжёлых инвазиях в организме человека ежедневно погибает около 100000 микрофилярий.

Общие симптомы зависят от интенсивности инвазии. Они включают повышенную температуру тела (в тяжёлых случаях до $39-40{ }^{\circ} \mathrm{C}$ ), головную боль, слабость, изменения кожи - она становится твёрдой, шелушится, появляется сыпь.

Характерный признак онхоцеркоза - наличие под кожей плотных фиброзных узлов размерами до 7 см. Узлы могут локализоваться как в тазобедренной области, так и около суставов, в области лопаток и редко на голове. У 40-50 \% жителей эндемичных районов в Африке повторная инвазия кожи паразитами приводит к персистирующему зуду. Частые расчёсывания вызывают соответствующие патоморфологические изменения кожи: дерматит, лихенизацию и, в конечном итоге, атрофические явления. Часто отмечается дегенеративное обвисание кожи в паховых областях. Характерна и депигментация кожи голеней по типу «кожи леопарда». В настоящее время разработана классификация кожных изменений при онхоцеркозе [16].

Серьёзность прогноза определяет поражение глаз. Риск развития слепоты зависит от заражённости эндемичной области мошками-переносчиками. Микрофилярии проникают на роговицу с кожи и конъюнктивы, вследствие чего развивается точечный кератит вокруг гибнущих микрофилярий. Если инвазия про- 
должается на протяжении многих лет, развивается склерозирующий кератит и иридоциклит, что и приводит к потере зрения. Кроме того, микрофилярии способны проникать в сетчатку и в сосуды, кровоснабжающие веки. Воспаление сетчатки в области выхода зрительного нерва также способно серьёзно нарушить зрение [11].

К нам обратилась женщина с жалобами на покраснение, жжение, отёк, сильную боль в левом глазу на протяжении десяти лет. Длительное время применяла обезболивающие препараты. Обследована в Германии в клинике Редгера, однако причины поражения глаза не установлены. С помощью валеодиагностики в левом глазу выявлен паразит Onchocerca volvulus, что подтвердилось лабораторно. Кроме того, в крови определялся герпес 7-го типа (100 тыс. копий) и очень высокий уровень IgG к вирусу V. zoster, которые и явились фоном клинических проявлений, что стало причиной неэффективности противовирусного лечения. Пациентка получила противопаразитарное лечение, а затем противовирусное с хорошим клиническим эффектом.

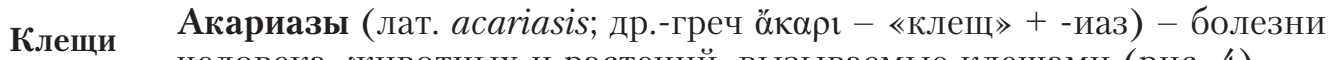

К акариазам относят такие болезни человека, как акариаз лёгочный, акародерматит, демодекоз и много других редких заболеваний органов и систем. Дискутируется роль клещей в развитии таких болезней, как ринофима, синдром Кавасаки, эритема мигрирующая хроническая.

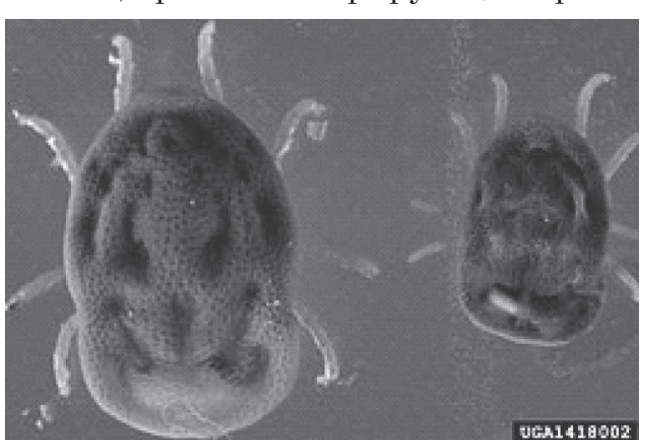

Рис. 4. Клещ Acarussiro под микроскопом (собственное наблюдение)

Акариазы относятся к арахнозам - болезням человека и животных, вызываемым паукообразными.

Клещи широко распространены в природе и, попадая в организм человека, могут вызывать не только поражение кожи, но и пищеварительного канала, органов дыхания, раздражение глаз (хотя, как правило, клещи не паразитируют во внутренних органах человека).

У диких и домашних животных (собаки, голуби, попугаи и др.) клещи паразитируют не только в коже, но и во внутренних органах.

Патогенные (чесоточный зудень) и условно-патогенные (демодекс) клещи вызывают паразитарные болезни человека (передают ему клещевые инфекции) и аллергию [7, 8].

Многие клещи являются временными эктопаразитами. Их укусы вызывают дерматит, зуд, раздражение кожи. Непаразитические клещи и их метаболиты вызывают аллергию, особенно при вдыхании гиперчувствительными людьми. Аллергия на клещей также может вызывать ринит и конъюнктивит. Укусы некоторых тропических клещей вызывают клещевой паралич [19].

Пища, загрязнённая некоторыми клещами, может вызвать острые желудочнокишечные расстройства (тошнота, рвота, понос), явления аллергического характера. Попадая в лёгкие человека с пылью при дыхании, эти клещи приводят к поражению лёгких.

Массовое поражение людей может быть обусловлено пузатым клещом - Pediculoides ventricosus (зерновая чесотка). Заболевание, как правило, возникает при непосредственном контакте с инфицированным зерном (погрузка, работа на складах и т. п.), а также с соломой, заражённой клещами. Поражение кожи проявляется высыпанием небольших папул или волдырей, сопровождающимся сильным зудом. Лечение всех этих видов чесотки заключается в назначении противозудных средств (1 \% ментоловый или 2 \% салициловый спирты, «болтушка», кортикостероидная мазь). Одновременно необходимо проводить дезинсекцию нательного и постельного белья, помещений. 
Клещи, их фрагменты и экскременты вызывают у чувствительных людей аллергию, чаще всего клинической манифестацией клещевой аллергии дыхательных путей являются аллергический ринит и бронхиальная астма [9].

Некоторые проявления внутреннего заражения клещами включают хроническую усталость, спорадический кашель, гипотиреоз, низкую температуру тела, артралгию, длительные грибковые заболевания, а также болезнь Лайма.

Заболевание, как правило, регрессирует после устранения причины. При иммунодефиците, а также при других хронических и умственных заболеваниях болезнь протекает тяжело, иногда наступает смерть больного.

Женщина 60 лет жаловалась на сильный зуд во всех участках тела. После почесывания возникала папула, из которой появлялся неизвестный паразит. Её жизнь превратилась в «хождение по мукам», а окружающие считали её психически нездоровой. Мы попросили собрать упомянутые паразиты и принести для исследования. При микроскопическом исследовании оказалось, что она, будучи в Египте, заразилась клещом рода акариаз, который живёт под кожей, что и привело к генерализации инфекции. После назначенной терапии клиническая симптоматика исчезла.

Плесневые грибы

Асперги́ллы (лат. Aspergillus) - род высших аэробных плесневых грибов, включающий несколько сотен видов, распространённых по всему миру в различных климатических условиях (рис. 5).

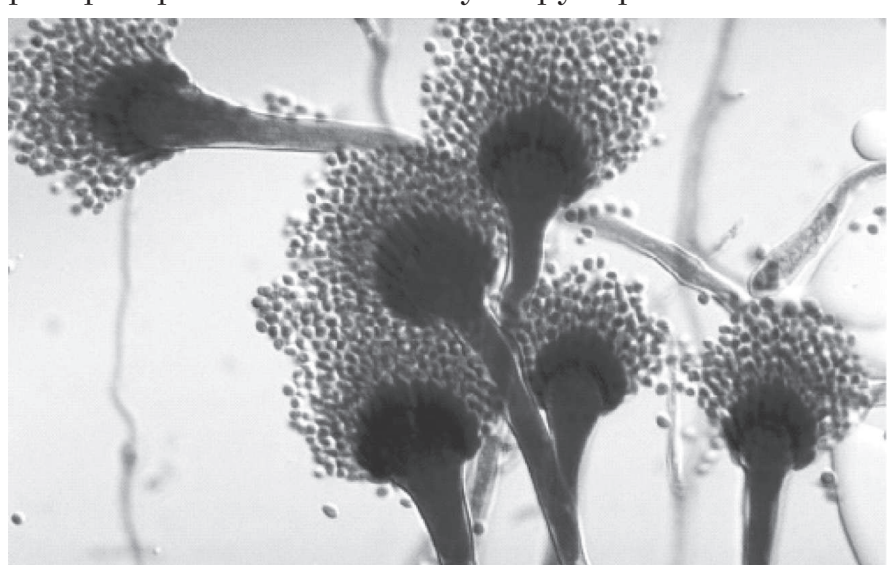

Рис. 5. Aspergillus fumigatus [14]

Аспергиллёз - группа заболеваний, вызываемых грибами рода Acпергилль. Наиболее распространённый подтип инфекций придаточных пазух носа, ассоциируемый с аспергиллёзом, вызывается видом $A$. fumigatus. Симптомы включают жар, кашель, боль в груди или одышку, что также проявляется и при многих других заболеваний и поэтому диагностика может быть усложнена. Обычно к этому заболеванию восприимчивы только пациенты с уже ослабленной иммунной системой или больные с другими лёгочными состояниями.

Некоторые виды аспергилл вызывают серьёзные заболевания у людей и животных. Чаще всего патогенность проявляют виды A. fumigatus и A. flavus, производящие афлатоксины, которые одновременно являются и токсинами, и гепатоканцерогенами. Они могут заражать пищу, например орехи, семена и зерно. Распространёнными возбудителями различных аллергических заболеваний являются виды A. fumigatus и A. clavatus. Другие виды важны как патогены сельскохозяйственных культур. Представители вида Аспергилль вызывают заболевания многих зерновых, особенно кукурузы; некоторые синтезируют микотоксины, включая афлатоксин [13, 14].

Главные формы заболевания у человека следующие:

- $\quad$ аллергический бронхолёгочный аспергиллёз, поражающий больных с респираторными инфекциями, такими как бронхиальная астма, муковисцидоз (кистозный фиброз) и синусит;

- острый инвазивный аспергиллёз - форма аспергиллёза, при которой грибки прорастают в окружающие ткани, чаще всего возникает у людей с ослабленной иммунной системой, например на фоне СПИДа или курсов химиотерапии;

- $\quad$ рассеянный инвазивный аспергиллёз - инфекция, широко распространившаяся в организме; 
- $\quad$ аспергилома - шаровидное грибковое образование, которое может сформироваться в пазухах и полостях, например в лёгких.

Чаще всего грибок проникает внутрь через дыхательные пути и рот, может поражать как дыхательную, так и центральную нервную систему, пищеварительный канал, кожу, органы чувств и половую систему. Аспергиллёзный менингит или энцефалит в большинстве случаев заканчивается летальным исходом. Встречаются также грибковые поражения аспергиллами селезёнки и почек, однако в большинстве случаев они вызваны вторичной инфекцией. Аспергиллёз дыхательных путей часто диагностируют у птиц, известны определённые виды $а$ спергилл, заражающие насекомых $[11,15,16]$.

Девочка 16 лет с южной области Украины обратилась к нам для иммунологического исследования с подозрением на опухоль мозга. Размер опухоли соответствовал куриному яйцу и она располагалась справа в лобной области. Мать от операции в Институте нейрохирургии отказалась. Через несколько месяцев начал выпячиваться правый глаз. В Москве в Институте им. Гельмгольца удалили глаз. При гистологическом исследовании выявлено образование aspergilius niger. После соответствующей терапии опухоль «aspergilius niger» в ткани мозга исчезла.

У мужчины 28 лет с множественными огнестрельными ранениями был разрушен правый локтевой сустав с дефектом кости. В госпитале Франции ему сформировали локтевой сустав, поставив выращенную кость. При выписке сохранялась субфебрильная температура тела, а через 2 нед она повысилась до $39-40{ }^{\circ} \mathrm{C}$, покраснел и опух сустав, появилась боль. Множественные антибиотики, назначенные пациенту, были неэффективны, больной обратился в нашу клинику. При обследовании обнаружены антитела к плесени в агрессивном количестве и дефицит IgG. После пяти капельниц Дифлюкана и дезинтоксикационной терапии температура тела снизилась, боль прошла. Пациент получил три капельницы по 50 мл 5 \% Октагама внутривенно. Сустав сохранён, больной выздоровел.

Выводы. Таким образом, описанные случаи неклассических редких заболеваний требуют особого внимания к различным паразитарным заболеваниям. Часто под «маской» неизвестной идиопатической патологии с аллергическими, аутоиммунными проявлениями могут скрываться различные паразитарные болезни, требующие от врача тщательного сбора анамнеза и диагностики. Лечение больных следует начинать с установления этиологического фактора на любом уровне, и пока не выявлен патоген, лечение не может быть эффективным.

Автор выражает благодарность К. А. Киевеч (набор материала), М. И. Ищенко (поиск паразитов), Е. И. Сидоренко, Т. В. Войтюк, И. И. Солонько, В. В. Дюсеевой, Н. Дукельськой, участвующих в подготовке материалов статьи.

$$
\text { Спи сок ли те ратуры }
$$

1. Давыдов О. Н., Куровская Л. Я., Темниханов Ю. Д. Личинки гельминтов гидробионтов, патогенные для человека и теплокровных животных / / Гидробиол. журн. - 2004. - Т. 40, № 3. - С. 103-111.

2. Audicana M. T., Kennedy M. W. Anisakis simplex: from obscure infectious worm to inducer of immune hypersensitivity / / Clin. Microbiol. Reviews. - 2008. - Vol. 21, N 2. - P. 360-379.

3. Bhat M., Cleland P. Gastric anisakiasis // Clin. Gastroenterology and Hepatology. - 2010. Vol. 8, N 8. - P. 20-24.

4. Chitsulo L. D., Engels D., Montresor A., Savioli L. Global status of schistosomiasis // Acta Trop. 2000. - Vol. 77. - P. 41-51.

5. Colley D. G., Bustinduy A. L., Secor W. E., King C. H. Human schistosomiasis // Lancet. - 2014. Vol. 383, N 9. - P. 64-70.

6. Gryseels B., Polman K., Clerinx J., Kestens L. Human Schistosomiasis. // Lancet. - 2006. Vol. 368, N 10. - P. 126-132.

7. Hengge U. R., Currie B. J., Jager G. et al. Scabies: a ubiquitous neglected skin disease //Lancet. 2006. - Vol. 6. - P. 769-779. 
8. HeukelbachJ., Feldmeier H. Scabies // Lancet. - 2006. - Vol. 367.- P. 1767-1774.

9. Hinman E., Kampmeier R. H. Intestinal ascariasis due to Tyroguphaslongior Gavais // Am. J. Trop. Med. - 1934. - Vol. 14. - P. 355-362.

10. Hochberg N. S., Hamer D. H. Anisakidosis: perils of the deep // Clin. Infectious Diseases. 2010. - Vol. 51, N 7. - P. 806-812.

11. Leung V., Miller M. Detection of scabies: A systematic review of diagnostic methods // Can. J Infect Dis Med Microbiol. - 2011. - Vol. 22, N 4. - P. 143-146.

12. Lustigman $S$., McCarter J. P. Ivermectin Resistance in Onchocerca volvulus: Toward a Genetic Basis // PLOS Neglected Tropical Diseases. - 2007. - Vol. 1, N 1. - P. 76-82.

13. Miles Matthew C., Peters Stephen P. Allergische bronchopulmonale Aspergillose (ABPA). https://www.msdmanuals.com/de/heim.

14. Pamela P. Lee and Yu-Lung Lau. Cellular and Molecular Defects Underlying Invasive Fungal Infections - Revelations from Endemic Mycoses // Front Immunol. - 2017. - Vol. 8. P. 735-741.

15. Sil A., Andrianopoulos A. Thermally dimorphic human fungal pathogens - polyphyletic pathogens with a convergent pathogenicity trait // Send to Cold Spring. Harb. Perspect. Med. 2014. - Vol. 8, N 5. - P. a019794. doi: 10.1101/cshperspect.a019794.

16. Tamarozzi F., Halliday A., Gentil K. et al. Onchocerciasis: the Role of Wolbachia Bacterial Endosymbionts in Parasite Biology, Disease Pathogenesis, and Treatment // Clin. Microbiol. Reviews. - 2011. - Vol. 24, N 3. - P. 459-468.

17. Yoon W.J., Lee S. M., Lee S. H., Yoon Y. B. Gastric anisakiasis // Gastrointestinal. Endoscopy. 2004. - Vol. 59, N 3. - P. 400-409.

18. Yorimitsu N., Hiraoka A., Utsunomiya H. et al. Colonic intussusception caused by anisakiasis: a case report and review of the literature // Internal. Med. - 2013. - Vol. 52, N 2. - P. $223-$ 226.

19. Zhao Y. Q., Zhen T. M., Cheng P. et al. Investigation and control of pulmonary acariasis pathogeny and its epidemic status // Chin. J. Hygienic. Insecticides Equipments. - 2007. - Vol. 13. P. 435-438.

ДОВГИЙ ШЛЯХ ДО ЗЦІЕННЯ

(рідкісні некласичні захворювання людини)

\section{В. С. Казмірчук (Київ)}

Наведено випадки некласичних рідкісних захворювань, які вимагають особливої уваги до різних паразитарних захворювань. Найчастіше під «маскою» невідомої ідіопатичної патології з алергічними, аутоімунними проявами можуть ховатися різні паразитарні хвороби, що вимагають від лікаря ретельного збору анамнезу та діагностики. Лікування пацієнтів слід починати з встановлення етіологічного фактора на будь-якому рівні і поки не буде виявлено патоген, лікування не може бути ефективним.

Ключові слова: паразити, імунітет, шистосомоз, анізакіди, акаріази, гриби аспіргільози, онхоцеркози.

\section{A LONG WAY TO HEALTHING}

(rare nonclassical human diseases)

\section{E. Kazmirchuk (Kyiv, Ukraine)}

Limited Liability Company "Institute of Immunology, Allergology and Rehabilitation”

Thus, the cases of nonclassic rare diseases listed in the article require special attention to various parasitic diseases. Often, under the guise of an unknown idiopathic pathology with allergic, autoimmune manifestations, various parasitic diseases can be concealed, requiring the doctor to carefully collect anamnesis and diagnosis. Treatment of patients should begin with the search for an etiological factor at any level, starting with the family doctor. Until the pathogen treatment is identified, it can not be effective.

Key words: helminths, immunity, schistosomiasis, anisacidosis, akariasis, aspergillus, onchocerciasis. 